\title{
Rola pytań w rozwijaniu przedsiębiorczości uczniów w młodszym wieku szkolnym
}

\section{The Role of Questions in Developing Entrepreneurship of Younger School-Age Students}

Streszczenie: W artykule podjęta została tematyka dotycząca roli pytań w rozwijaniu przedsiębiorczości uczniów w młodszym wieku szkolnym. Celem artykułu było ukazanie, jaką rolę w kształtowaniu postawy przedsiębiorczej dzieci pełnią pytania według taksonomii Blooma, uzyskanie informacji, jakiego rodzaju pytania w praktyce stosują badani nauczyciele edukacji wczesnoszkolnej oraz jak postrzegają oni przedsiębiorczość. Treści artykułu wzbogacono wynikami badań sondażowych z wykorzystaniem techniki ankiety. Uzyskane dane wskazują, że badani nauczyciele głównie deklarują stosowanie pytań z niższych poziomów organizacji myślenia (wiadomości, rozumienia, zastosowania), które w mniejszym zakresie niż pytania z poziomu oceniania, analizy i syntezy pobudzają uczniów do bardziej złożonych operacji myślowych. Większość respondentów postrzega przedsiębiorczość szeroko i wykracza poza ekonomiczne ujęcie zagadnienia. Badani nauczyciele potrafią wskazać nieliczne strategie rozwijania przedsiębiorczości, jednak brak wśród nich strategii formułowania pytań prowokujących do myślenia i pogłębionej refleksji. Uzyskana wiedza może stać się przyczynkiem do zwrócenia uwagi obecnych i przyszłych nauczycieli na ten ważny aspekt rozwijania i pobudzania przedsiębiorczości. Artykuł zawiera także przykłady strategii i dobrych praktyk wykorzystujących pytania w rozwijaniu postawy przedsiębiorczej uczniów.

\begin{abstract}
The article deals with the subject of the role of questions in developing entrepreneurship in younger school-age students. The aim of the article was to show, according to Bloom's taxonomy, the role that questions play in shaping the entrepreneurial attitude of children, obtain information on the kinds of questions used in practice by the surveyed early childhood education teachers and how they perceive entrepreneurship. The content of the article was enriched with the results of surveys using the survey technique. The obtained data indicate that the surveyed teachers mainly declare the use of questions from the lower levels of thinking organisation (knowledge, understanding, application), which to a lesser extent stimulate students to more complex mental operations than questions from the level of assessment, analysis and synthesis. Most of the respondents see entrepreneurship broadly and go beyond the economic perspective of the issue. The surveyed teachers are able to indicate a few strategies for de-
\end{abstract}


veloping entrepreneurship, but among them there are no strategies for formulating thought-provoking questions and in-depth reflection. The acquired knowledge may become a contribution to drawing the attention of current and future teachers to this important aspect of developing and stimulating entrepreneurship. The article also includes examples of strategies and good practices that use questions to develop an entrepreneurial mindset in students.

Słowa kluczowe: edukacja wczesnoszkolna; opinie nauczycieli; przedsiębiorczość; rola pytań

Keywords: early school education; entrepreneurship; teacher opinions; the role of questions

Zaakceptowano: 27 marca 2020

Otrzymano: 27 March 2020

Received: 31 lipca 2020

Accepted: 31 July 2020

Sugerowana cytacja/Suggested citation:

Sufa, B. (2020). Rola pytań w rozwijaniu przedsiębiorczości uczniów w młodszym wieku szkolnym. Przedsiębiorczość - Edukacja [Entrepreneurship - Education], 16(2), 61-72. doi: $10.24917 / 20833296.162 .5$

\section{Wstęp}

W kształtowaniu postawy przedsiębiorczej, charakteryzującej się inicjatywą, poczuciem sprawstwa, proaktywnością, otwartością, odwagą intelektualną i wytrwałością w dążeniu do celu, istotną rolę odgrywa strategia stawiania trafnych pytań, rozwijających i stymulujących myślenie twórcze i krytyczne uczniów. Celem niniejszego artykułu było ukazanie znaczącej roli pytań w rozwijaniu przedsiębiorczości uczniów w młodszym wieku szkolnym oraz uzyskanie informacji, jakiego rodzaju pytania wykorzystują w praktyce badani nauczyciele edukacji wczesnoszkolnej z losowo wybranych krakowskich szkół podstawowych. Wyniki badań sondażowych przeprowadzonych w listopadzie 2019 r. wskazują na niedostatki w zakresie wykorzystania przez nauczycieli pytań produktywnych z wyższych poziomów organizacji myślenia (analizy, syntezy, oceniania), które pobudzają uczniów do bardziej złożonych operacji myślowych oraz na nieznaczną wiedzę badanych w zakresie strategii rozwijania przedsiębiorczości uczniów. Uzyskane wyniki nie miały służyć formułowaniu uogólnień czy stawianiu tez, lecz ukazać, jakiego rodzaju pytania w rozwijaniu przedsiębiorczości uczniów są istotne i jakie są wykorzystywane w praktyce przez badanych nauczycieli, co może stać się przyczynkiem do zwrócenia uwagi nauczycieli na ten ważny aspekt kształtowania postawy przedsiębiorczej uczniów.

\section{Znaczenie pytań w rozwoju przedsiębiorczości dziecka a rzeczywistość szkolna}

W procesie edukacyjnym szczególne znaczenie mają pytania twórcze i refleksyjne, ponieważ za ich pomocą można m.in. skłonić do namysłu, pobudzić do twórczych, elastycznych działań, krytycznych sądów i opinii popartych trafną argumentacją oraz stworzyć okazję do generowania oryginalnych, nietypowych pomysłów, które odgrywają znaczącą rolę w kształtowaniu kompetencji w zakresie przedsiębiorczości. Kompetencje te opierają się na: kreatywności; krytycznym myśleniu i niekonwencjonalnym rozwiązywaniu problemów; odpowiedzialności; podejmowaniu inicjatywy, wyważonego ryzyka, przy równoczesnym zachowaniu zasad etycznych; przewidywaniu konsekwencji działań; 
wytrwałości, pasji oraz na zdolności do wspólnego działania służącego zaplanowaniu projektów mających na celu wartość kulturalną, społeczną lub finansową i zarządzanie nimi (Brzezińska, Szmidt, 2008).

Psychologowie, akcentując funkcję poznawczą i interpersonalną pytań, ukazują ich znaczenie w osiąganiu przez dziecko orientacji w rzeczywistości, zdobywaniu i poszerzaniu przez nie wiedzy o świecie, wskazują też na ich istotną rolę w procesie interakcji oraz stymulacji myślenia twórczego i krytycznego jako potencjalnych determinantów rozwoju przedsiębiorczości. Dostrzeganie, odkrywanie problemów przez pytania jest czynnością decydującą o wybitnych osiągnięciach twórczych w różnych dziedzinach, które bardziej wynikają z twórczego zdefiniowania różnych problemów niż ich rozwiązania. Dlatego formułowaniu produktywnych pytań przez nauczyciela powinno towarzyszyć stawianie pytań przez dziecko podczas celowo organizowanych sytuacji dydaktycznych wymagających namysłu, twórczego rozwiązywania problemów oraz twórczej i krytycznej refleksji. E. Nęcka (2001) i R. Fisher (1999) podkreślają, że zdolność myślenia pytajnego jest niezbędna w procesie poznawania i twórczego przekształcania świata. Niestety, z raportów badawczych wyłania się obraz szkoły jako środowiska, które nie stymuluje zdolności pytajnych uczniów, a nawet powoduje ich zanik w miarę postępów edukacyjnych. W środowisku szkolnym bagatelizuje się refleksyjność wypowiedzi, hipotezy stawiane przez uczniów, mowę eksploracyjną dopuszczającą wahanie się, czy zauważanie problemów w otaczającej rzeczywistości (Turska, 2006). Niezależne myślenie dziecka często jest odbierane przez uczącego jako nieposłuszeństwo, arogancja, niezdyscyplinowanie, a pytający uczeń uważany jest za intruza. U podstaw tłumiona są więc: kreatywność, myślenie twórcze i refleksyjne u uczniów (Zoller, 2009).

W opinii D. Klus-Stańskiej (2000) braki w zakresie stymulowania myślenia pytajnego wynikają z faktu, że nauczyciel transmisyjny bardziej chce sprawdzić, co uczeń wie, niż próbuje odkryć, co go interesuje. Jak wskazuje Nęcka (2001), przekazywanie dzieciom wiedzy jałowej, rzadko odwołującej się do kontekstu społecznego i poznawczego, umożliwia rozwiązywanie trudnych, ale nie nowatorskich problemów, co zapobiega twórczości, godząc w kluczowy moment formułowania celów. Zastosowanie mniej ścisłych form językowych w nauczaniu może sprawić, że zacznie rozwijać się tzw. wiedza płodna, odnosząca się nie tylko do tego, co znane, ale też do tego, co można odkryć (Nęcka, 2001).

Biorąc pod uwagę istotę i znaczenie pytań dla rozwoju dziecka we współczesnej szkole powinno się zatem dążyć do wykształcenia ucznia poszukującego i stawiającego pytania, o postawie badawczej, twórczej, niezależnej, odważnej, a jednocześnie ucznia krytycznego, refleksyjnego i obiektywnego w stosunku do przyjmowanych informacji (Paul, Binker, Charbonneau, 1996).

Pytania ukierunkowane na kształtowanie postawy przedsiębiorczej powinny rozwijać zmysł inicjatywy, poczucie sprawstwa, proaktywność, otwartość na przyszłość i wytrwałość w dążeniu do celu. Powinny także przygotowywać dzieci do przejmowania kontroli nad własnym życiem i własnymi wyborami, pobudzać je do generowania pomysłów, przewidywania konsekwencji działania, określenia możliwości i szans, swoich mocnych i słabych stron.

W szkole należy zatem stwarzać uczniom okazję do pobudzania różnych poziomów myślenia w różnych sytuacjach, przez stosowanie różnych metod dydaktycznych (m.in. aktywizujących, projektów, dram) i różnych strategii, w tym strategii formułowania trafnych pytań. 
Strategie formułowania trafnych pytań w rozwijaniu przedsiębiorczości

Uporządkowanie pytań według narastającej złożoności myślenia, począwszy od prostych pytań pamięciowych, następnie pytań wymagających rozumienia i wyjaśniania, do pytań z zakresu analizy, syntezy i oceniania stanowi dobrą strategię przy formułowaniu pytań. Nauczyciel powinien zatem rozpoczynać od pytań opisowych: Co?, Jak?, a potem stawiać pytania: Dlaczego?, Po co?, wymagające większego namysłu i bardziej skomplikowanych odpowiedzi. Pytania nauczyciela powinny więc dać uczniom sposobność, by łączyć to, co już wiedzą, z tym, co trzeba zbadać, a więc do zastanowienia się nad własnym myśleniem (Fisher, 1999).

Dobre pytanie mieści się w układzie pytań tak przemyślanym, żeby zadania stawiane przed uczeniem się były wydajne i prowadziły „w górę” tzw. taksonomii Benjamina Blooma, traktowanej jako model, według którego zarówno nauczyciele, jak i uczniowie mogą stawiać pytania sobie i innym (Fisher, 1999). W taksonomii Blooma wyróżnia się różne rodzaje poziomów myślenia i odpowiadające im procesy myślowe. Niższy poziom organizacji myślenia obejmuje: wiadomości (zapamiętywanie i przypominanie): Kto...?, Co...?, Gdzie...?, Kiedy....?, Jak...?; rozumienie (interpretowanie i pojmowanie): Co rozumiesz przez ...? Wyjaśnij... Opisz własnymi słowami, Powiedz, co o tym sadzisz, Wytłumacz..., Porównaj..., Powiąż....; zastosowanie (wykorzystanie): Jakie jeszcze przykłady można znaleźć?, Jak można to wykorzystać do rozwiązania problemu?, Do czego to prowadzi?, Użyj tych wiadomości do rozwiązania problemu, Zademonstruj, jak można to wykorzystać, do czego... Wyższy poziom organizacji myślenia obejmuje natomiast: analizę (rozkładanie na części): Jaki jest dowód na ...? Jak to udowodnić?, Jak to sprawdzić?, Jakie są właściwości czegoś?; syntezę (łączenie): Jak można polepszyć..., zaprojektować lub rozwiązać...; ocenianie (osądzanie, szacowanie): Co o tym myślisz?, Według jakich kryteriów to szacujesz, osądzasz?

$\mathrm{W}$ rozwijaniu przedsiębiorczości można wykorzystać różne rodzaje pytań z różnych poziomów organizacji myślenia, jednak szczególnie przydatne mogą okazać się pytania wyższego rzędu z zakresu oceniania, syntezy i analizy.

Formułowane przez nauczyciela pytania zachęcające uczniów do myślenia, jednocześnie rozwijające postawę przedsiębiorczą, mogą przybrać postać typu: Co o tym myślisz?, Dlaczego tak myślisz?, Na jakiej podstawie tak sądzisz?, Skąd masz taką wiedzę/ skąd to wiesz?, Czy masz jakiś dowód?, Skąd bierzesz pewność?, Czy tak jest zawsze?, Czy jest jakiś pomysł (sposób, powód)?, Czy mógłbyś podać jakiś inny przykład?, Co stanie się, jeśli...?, Co może zdarzyć się potem?, Co będzie, jeżeli nie...?, Czy jest możliwe, że...?, Co przez to rozumiesz? Przez odpowiedzi na tego typu pytania możliwe jest m.in. uzewnętrznianie przemyśleń i koncepcji, stawianie hipotez, rozumowanie, przewidywanie, argumentowanie. Odkrywanie celów, powodów danej działalności jednocześnie uświadamia dzieciom, że jest to wiedza istotna, aby zrobić daną rzecz w określony sposób, chociaż powody i sposoby mogą być różne, odmienne.

Pobudzanie krytycznej refleksji, zdolności do sądów krytyczno-analitycznych, sceptycyzmu, ciekawości prowokuje dzieci nie tylko do zadawania pytań: Po co coś robimy?, ale także: Dlaczego to robimy?, W jaki sposób można to zrobić, ulepszyć? itp.

Trafne pytania stanowią zatem wyzwanie dla myślenia, inspirują, wspomagają namysł, są otwarte na różne możliwości i problemy oraz wymagają często nietypowych, nieschematycznych i przemyślanych odpowiedzi. Pytania takie mogą przybierać następujące formy: 
- pytania skupiające uwagę - produktywne, typu: Widziałeś?, Zauważyłeś?, Co to jest?, które otwierają przestrzeń do badań, kierują uwagę na określone szczegóły, prowokują do poszukiwania argumentów, dowodów i założeń;

- pytania wymuszające porównanie - skupiające uwagę na specjalnych sprawach, takie jak: Ile?, Jak długo?, Jak często?, umożliwiające dzieciom porównanie podobnych obiektów, precyzyjne klasyfikowanie i wprowadzanie porządku do dokonywanych obserwacji;

- pytania domagające się uściślenia - pomagające skupić się na znaczeniu i sensie wypowiadanych słów oraz pozwalające zastanowić się nad własnym sposobem myślenia: Co chciałeś przez to powiedzieć?, Czy mógłbyś to wyjaśnić?, Czy mógłbyś podać przykład?, Czy mógłbyś pokazać, zaprezentować...?, Powiedz to inaczej, w inny sposób...;

- pytania, które zachęcają do badania - Co powinieneś wiedzieć?, Jak możemy się tego dowiedzieć?, Jak możemy to poznać?, Jak należy to zrobić?, Co stanie się, jeżeli...?;

- pytania o powody (w pewnym sensie pytania o wyjaśnienie) - Skąd to wiesz?, Na jakiej podstawie tak twierdzisz?, Jakie masz dowody?, dotyczące procesu rozumowania, dokonywania namysłu nad uzyskanymi danymi i własnymi odpowiedziami (Fisher, 1999).

Wyróżnione pytania pobudzają ciekawość uczniów, ich badawczą postawę, dociekliwość i czujność, prowokują do poszukiwania rozwiązań.

Celowe w rozwijaniu przedsiębiorczości mogą okazać się także pytania uświadamiające uczniom ich skuteczność, a szczególnie takie, które odnoszą się do jej składowych: zaangażowania i wkładu pracy w podejmowane działania, wytrwałości w realizacji zadania, oceny własnych działań, efektywności własnej, oceny siebie w relacji z innymi, świadomości swoich zasobów, radzenia sobie z rozwiązywaniem problemów (Sufa, Grzywniak, Vaskevic-Buś, 2019). Pytania wzmacniające u uczniów poczucie własnej skuteczności istotnej w rozwijaniu postawy przedsiębiorczej mogą także przybrać postać pytań coachingowych (np. technika C5: Co możesz robić więcej, żeby było więcej...?, Co możesz robić mniej, żeby było więcej...?, Co możesz robić inaczej, żeby było więcej...?, Co możesz przestać robić, żeby było więcej...?, Co możesz zacząć robić, żeby było więcej...?).

Płynność i elastyczność procesu generowania pytań można polepszyć, ćwicząc stawianie pytań na zróżnicowanym materiale, by uczniowie mogli więcej dostrzegać we wskazanym obiekcie, więcej myśleć i uczyć się o nim.

W kształtowaniu przedsiębiorczości dzieci w młodszym wieku szkolnym istotną rolę odgrywają również zdolności: mobilizowania zasobów (ludzi i przedmiotów); gospodarowania posiadanymi środkami; podejmowania drobnych decyzji finansowych związanych z kosztem i wartością; planowania przedsięwzięć, by osiągnąć zamierzone cele; zauważania i wykorzystywania szans; identyfikacji własnych mocnych i słabych stron, dostępnych możliwości; oceny ryzyka; przewidywania konsekwencji swoich działań; proaktywnego zarządzania projektami (obejmującego np. planowanie, organizowanie, zarządzanie, kierowanie zadaniami i zlecanie zadań, analizowanie, komunikowanie, negocjowanie, prezentację pomysłów i ocenę) oraz świadomość wartości etycznych. W rozwijaniu przedsiębiorczości uczniów cenne będą także pytania pobudzające do namysłu nad własną skutecznością w pracy indywidualnej i zespołowej (sprzyjającej innowacyjnemu zastosowaniu wiedzy), szczególnie pytania z poziomu oceniania, odnoszące się do oceny: celów, skuteczności zaplanowanych działań, własnego zaangażowania, wysiłku w wykonanie zadania, podjętego ryzyka, okazji i osobistych zasobów, zarządzania pracą 
grupy, prezentacji pomysłów, słabych i mocnych stron, przyjmowania krytyki, radzenia sobie z porażką.

\section{Warunki wspomagania myślenia twórczego i refleksyjnego uczniów w rozwijaniu przedsiębiorczości}

Zmiana podejścia do nauczania i uczenia się wymaga tworzenia warunków do rozwijania postawy badawczej (burzącej ramy oczywistości), ciekawości (w tym ciekawości poznawczej) uczniów i „wychowania ich do niepokoju” (Witkowski, 2007). Brak poczucia oczywistości, pewności, potrzeba zmiany, niewiedza wyzwalają potrzebę formułowania pytań i pobudzają czujność intelektualną, umożliwiającą stawianie znaków zapytania przy pozornie oczywistych faktach i prawdach o otaczającej rzeczywistości. Wykorzystując myślenie pytajne, uczeń może zredefiniować znane problemy, a następnie nadać im nowe znaczenie. Myśląc w sposób asocjacyjny, transformacyjny, metaforyczny, indukcyjny, dedukcyjny dziecko tworzy nowe idee przez łączenie, modyfikowanie, przekształcanie znanych pomysłów w nowy, nietypowy, oryginalny sposób. Myślenie refleksyjne pozwala odkryć informacje dotyczące problemu, lepiej go zrozumieć, co wpływa znacząco na wnioskowanie jednostki, które nadaje indywidualną strukturę dziełu twórczemu (Runco, 2003). Te cenne umiejętności są niezbędne w codziennej praktyce, są także nieocenione w kształtowaniu postawy przedsiębiorczej.

To, czy uczniowie będą stawiać pytania i będą prezentować postawę przedsiębiorczą, w znacznym stopniu zależy od nauczyciela i jego postawy, a szczególnie od tego, jak dzieci reagują na jego pytania (Sternberg, Sperar-Swerling, 2003). Nauczanie dzieci przedsiębiorczości powinno uwzględniać zmianę nawyków nauczyciela. Zamiast detalicznego instruktażu ze strony nauczyciela i nieustannie ponawianych wskazówek, jak prawidłowo wykonać zadanie oraz egzekwowania wyniku i trybu postępowania, winny pojawić się pytania pobudzające twórcze i krytyczne myślenie, ciekawość poznawczą, uwzględniające niezależność najmłodszych uczestników interakcji. Trzeba, aby refleksyjny wychowawca brał pod uwagę, czy i jak może towarzyszyć dzieciom w tym, co i jak one chciałyby samodzielnie zrobić i osiągnąć (Axelsson, Hägglund, 2015). By ten cel osiągnąć, nauczyciele powinni mieć świadomość, że sami powinni być wyposażeni w kompetencje szeroko pojętej przedsiębiorczości, co przekłada się na ich myślenie i działania w zakresie edukacji przedsiębiorczej dzieci. Tymczasem, jak wykazały badania M. Kondrackiej-Szali (Kondracka-Szala, Malinowska, 2016), przygotowanie i doskonalenie nauczycieli przedszkoli niemal zupełnie nie uwzględnia tych kwestii. Podobną tezę można sformułować także w związku z kształceniem nauczycieli edukacji wczesnoszkolnej.

Aktywny stosunek pedagogów do dzieci i przedsiębiorczości własnej wymaga świadomego kształtowania stosownej postawy (Ir, Janiszewska, 2015). Rozwijanie swoich kompetencji, obiektywizacja samooceny w celu zidentyfikowania mocnych i słabych stron, asertywność, koncentracja na osiąganiu celów połączona z podejmowaniem ryzyka oraz poszukiwanie kreatywnych rozwiązań, skuteczna komunikacja i współpraca z otoczeniem - stanowią właściwe zawodowi wymiary przedsiębiorczości (Oelszlaeger-Kosturek, 2017).

Stymulując warunki do myślenia twórczego, krytycznego i refleksyjnego, które są istotne dla kształtowania przedsiębiorczości, nauczyciel powinien m.in.:

- nie obawiać się pytań uczniowskich i prowokować dzieci do zadawania pytań, nie jest bowiem ważne, o co pytają, ale że w ogóle pytają, 
- doceniać, chwalić, nagradzać pytania, sam fakt ich pojawienia się, a nie tylko formę czy treść, zwracając uwagę na zasady kultury osobistej i intencje osoby pytającej,

- nie obawiać się ujawnienia własnej niewiedzy, co stanowi punkt wyjścia do wspólnych poszukiwań, porównania zdobytych informacji,

- stawiać pytania otwarte, zachęcające do poszukiwania wielu możliwych rozwiązań, rozwijające produktywność i oryginalność myślenia,

- nie odpowiadać od razu na niektóre istotne pytania, które powinny przez jakiś czas pozostać bez odpowiedzi, co prowokuje dzieci do myślenia,

- zadawać mniej pytań, ale trafnie sformułowanych, lepszych jakościowo, poczynając od pytań prostych po bardziej złożone, z wyższych poziomów organizacji myślenia,

- stosować pauzę po zadaniu pytania, by po kilkunastu sekundach otrzymać odpowiedź ucznia,

- odpowiadać na pytania uczniów z szacunkiem, nawet gdy wydają się one trywialne, mało odkrywcze,

- założyć w klasie tablicę pytań, na której można wpisywać ważne i wartościowe pytania,

- modelować zachowania pytajne - dzielić się z uczniami swoimi pytaniami i zakłopotaniem poznawczym,

- dyskutować z uczniami na temat pytań, ich istoty, celu,

- nauczyć dzieci rozróżniania i formułowania pytań otwartych i zamkniętych,

- zachęcać uczniów do formułowania różnorodnych rodzajów pytań, w tym pytań hipotetycznych (Co by było, gdyby?, Co stanie się, jeśli...?), od pytań faktograficznych do pytań odkrywczych, produktywnych.

Rola pytań w rozwijaniu przedsiębiorczości uczniów

w młodszym wieku szkolnym - wyniki badań własnych

Celem podjętych badań było ustalenie, jakiego rodzaju pytania są głównie wykorzystywane przez nauczycieli edukacji wczesnoszkolnej w celu rozwijania przedsiębiorczości uczniów. Ponieważ wiedza nauczycieli na temat przedsiębiorczości może mieć znaczenie w wyborze strategii rozwijania przedsiębiorczości dzieci (Kondracka-Szala, Malinowska, 2016), zasadne było także poznanie opinii badanych na temat przedsiębiorczości. Do badań wykorzystano metodę sondażu diagnostycznego, która umożliwia badanie zjawisk społecznych, opinii i poglądów określonych zbiorowości (Pilch, 1995) oraz zastosowano technikę ankiety. Zastosowane narzędzie badawcze to formularz ankiety, który zawierał pytania otwarte, zamknięte i wielokrotnego wyboru.

Do analizy zakwalifikowano 66 kwestionariuszy ankiet. Badania przeprowadzono w listopadzie 2019 i objęły one nauczycieli edukacji wczesnoszkolnej z losowo wybranych krakowskich szkół podstawowych. W badaniach o charakterze diagnostycznym, opisowym, nie postawiono hipotez badawczych zgodnie z założeniem, że jeżeli opisuje się badane fakty i/lub zjawiska, to nie ma konieczności formułowania hipotez roboczych (Łobocki, 1984: 75). Uzyskane wyniki pozwoliły m.in. określić: jakiego rodzaju pytania badani nauczyciele wykorzystują w praktyce w celu rozwijania przedsiębiorczości dzieci, jak definiują pojęcie przedsiębiorczości, jakie cechy nadają osobie przedsiębiorczej oraz jakie znają sposoby rozwijania przedsiębiorczości dzieci. 
Respondenci spośród podanych rodzajów pytań, z różnych poziomów organizacji myślenia, wskazali te, które wykorzystują w toku zajęć, oraz te, które ich zdaniem są przydatne w kształtowaniu postaw przedsiębiorczych dzieci. Szczegółowa analiza danych ukazuje, że ankietowani używają głównie pytań z niższych poziomów organizacji myślenia (z zakresu wiadomości, rozumienia, zastosowania), które wymagają mniej skomplikowanych operacji myślowych (rycina 1). Pytania bardziej złożone z wyższych poziomów organizacji myślenia, szczególnie z zakresu analizy i syntezy, uzyskały mniej wskazań. Najrzadziej typowane przez badanych były pytania z zakresu oceniania. Wszyscy respondenci (66 osób) wskazali, że spośród niższych form myślenia głównie wykorzystują pytania z zakresu wiadomości: Kto...?, Co...?, Gdzie...?, Kiedy....?, Jak...?. Zdecydowana większość ankietowanych (47 osób) stawia także pytania i zadaje polecenia z poziomu rozumienia (interpretowania i pojmowania) typu: Wyjaśnij..., Wytłumacz..., Porównaj..., Co rozumiesz przez...?. Nieznacznie mniej niż połowa badanych (32 osób) zaznaczyła, że stosuje również pytania z zakresu zastosowania (wykorzystania): Jak można to wykorzystać do rozwiązania problemu?, Do czego można to wykorzystać?, Jakie inne przykłady można jeszcze podać? Mniej niż połowa respondentów (26 osób) wskazała na stosowanie pytań z wyższych poziomów organizacji myślenia, z zakresu analizy. Są to pytania typu: Jak to sprawdzić?, Jak to udowodnić?. Część ankietowanych (24 osoby) wykorzystuje pytania z poziomu syntezy: Jak można ulepszyć...?, Jak można rozwiązać...? i zaledwie kilkunastu badanych nauczycieli (18 osób) zadeklarowało, że operuje pytaniami z poziomu oceniania: Co o tym myślisz?, Według jakich kryteriów to oceniasz?, Czym się kierowałeś, tak oceniając? Należy podkreślić, że część respondentów (18 osób) dodatkowo wskazała, że pytania z zakresu oceniania skłaniające uczniów do namysłu i refleksji m.in. nad oceną: zaplanowanego działania, zaangażowania i wysiłku w wykonanie zadania, ryzyka, pomysłów i ich prezentacji, mocnych i słabych stron, własnych zasobów i samoskuteczności prawie w ogóle nie są przez nich wykorzystywane w pracy z dziećmi. Uzyskane dane zaprezentowano na rycinie 1 .

Szczegółowa analiza wypowiedzi dotyczących trafnych pytań, z różnych poziomów organizacji myślenia, które badani wybrali z listy pytań i uznali za istotne w procesie rozwijania przedsiębiorczości dzieci, wskazuje, że przez większość respondentów (53 osoby) stosowane są pytania skupiające uwagę, prowokujące uczniów do poszukiwania argumentów, dowodów, założeń i odnajdywania szczegółów (rycina 2). Prawie połowa ankietowanych (32 osoby) deklaruje stosowanie pytań wymuszających porównania, które skupiają uwagę na sprawach specjalnych, takich jak: Ile?, Jak często?, Jak długo? i umożliwiają klasyfikację, uporządkowanie dokonanych obserwacji. Część badanych deklaruje stosowanie pytań domagających się uściślenia, skupienia się na znaczeniu wypowiadanych słów i pozwalających na zastanowienie się nad własnym sposobem myślenia: Co chciałeś przez to powiedzieć?, Czy mógłbyś to wyjaśnić/powiedzieć inaczej?, Czy mógłbyś podać przykład?. Nieznaczna liczba respondentów (14 osób) skłania uczniów do odpowiedzi na pytania zachęcające do badania: Jak możemy się tego dowiedzieć?, Jak należy to zrobić?, Co stanie się, jeżeli...?. Większość badanych nauczycieli (45 osób) zadeklarowało także stosowanie pytań o powody: Skąd to wiesz?, Na jakiej podstawie tak twierdzisz?, Jakie masz dowody?, które umożliwiają zastanowienie się nad uzyskanymi danymi, czy własnymi odpowiedziami. Zgromadzone dane zaprezentowano na rycinie 2.

Badani nauczyciele podjęli próbę zdefiniowania przedsiębiorczości, wskazując na elementy w ich opinii charakterystyczne dla tego terminu. Większość badanych pojmuje 
Rycina 1. Wykorzystanie przez nauczycieli pytań z różnych poziomów myślenia

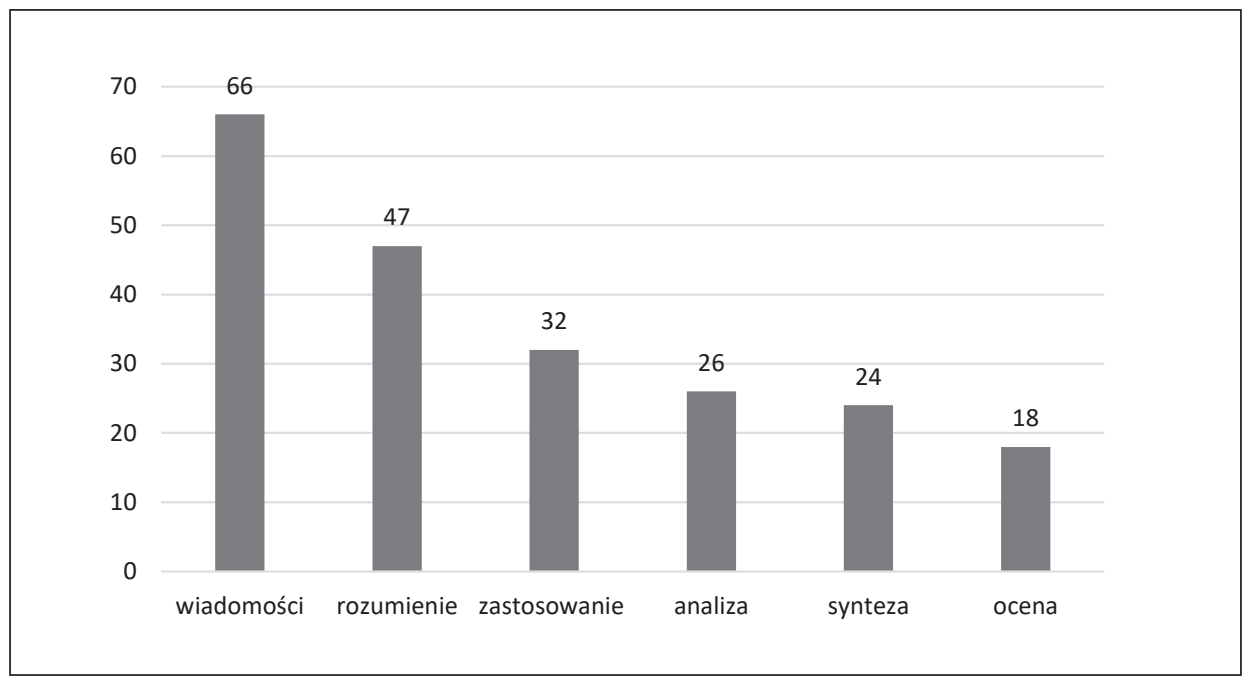

Źródło: opracowanie na podstawie badań własnych

Rycina 2. Wykorzystywanie trafnych pytań przez badanych nauczycieli

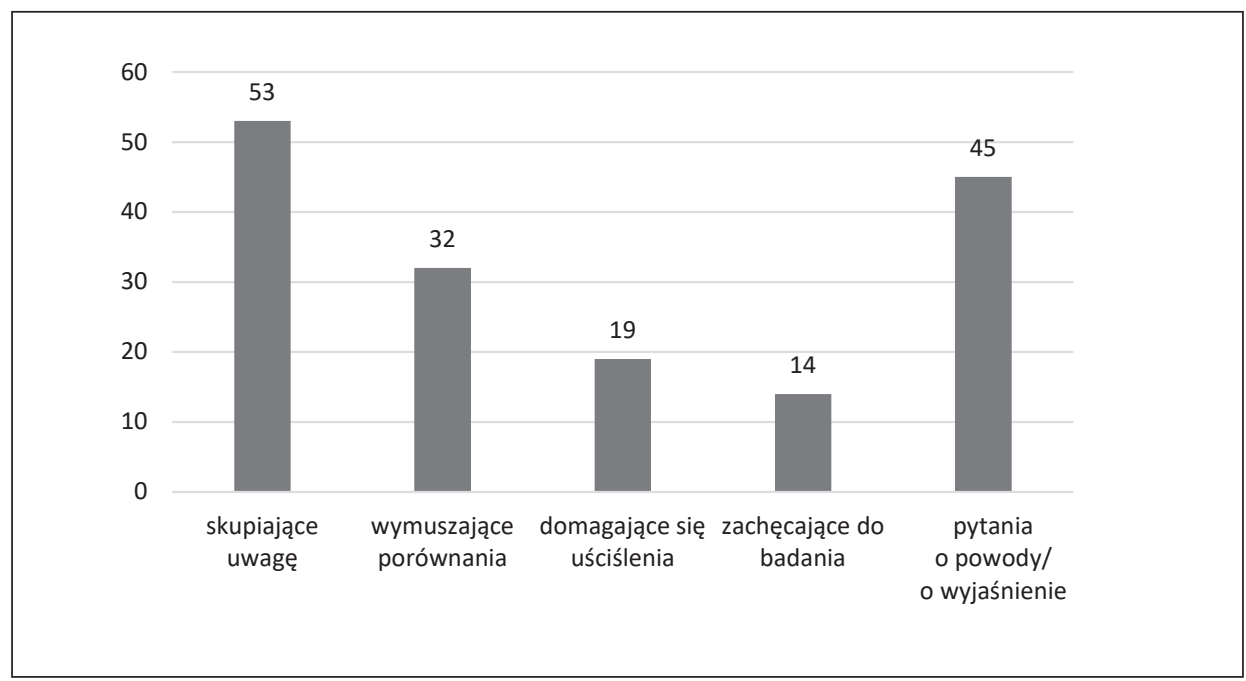

Źródło: opracowanie na podstawie badań własnych

przedsiębiorczość szeroko, wykraczając w swoich wypowiedziach poza ekonomiczne, wąskie ujęcie zagadnienia. Dla zdecydowanej większości badanych przedsiębiorczość wiąże się z podejmowaniem określonych decyzji albo przedsięwzięć (52 osoby), myśleniem twórczym (46 osób). Większość respondentów określiła ją jako przejmowanie inicjatywy (43 osoby). W opinii ankietowanych przedsiębiorczość jest równoznaczna z zaradnością i pomysłowością (36 osób), połowa badanych kojarzy ją z gotowością do osiągniecia zakładanego celu oraz realizacji własnych pomysłów (33 osoby), znaczna część badanych definiuje przedsiębiorczość jako umiejętność dostrzegania i wykorzystywania nadarzających 
się okazji (24 osoby). Ankietowani wiążą to pojęcie z organizowaniem swego życia (23 osoby), a znaczna część uważa, że jest to czynne działanie (28 osoby), niejednokrotnie w trudnych dla przeciętnego człowieka sytuacjach (14 osób), wymagające podejmowania ryzyka (12 osób).

Respondenci poprawnie zidentyfikowali cechy osoby przedsiębiorczej. W wachlarzu wymienianych cech charakteryzujących osobę przedsiębiorczą badani wskazali cechy pozytywne, takie jak: zaradność (52 osoby), pomysłowość (48 osób), twórczość (43 osoby), nowatorskość (26 osób), elastyczność (23 osoby), dynamiczne działanie (18 osób), ambicje (12 osób), umiejętność przewidywania (8 osób). Większość badanych oceniła się głównie jako osoby zaradne (47 osób) i pomysłowe (41 osób), nieznacznie mniej osób uznało się za osoby twórcze (36 osób). Część badanych zadeklarowała, że zna swoje mocne i słabe strony (32 osób). Uważając siebie za osoby przedsiębiorcze, prawie wszyscy ankietowani (58 osób) wskazali, że nie mieli okazji do rozwijania przedsiębiorczości ani w swojej formalnej, ani pozaformalnej edukacji i nie zostali przygotowani pod względem metodycznym do prowadzenia zajęć rozwijających przedsiębiorczość u dzieci. Część respondentów (17 osób) opowiedziała się za realizacją edukacji przedsiębiorczej już w przedszkolu i widziała też potrzebę kształcenia w tym zakresie przyszłych nauczycieli (12 osób). Ankietowani uważają także, że powinno się systematycznie rozwijać przedsiębiorczość dzieci, żeby ich przygotować do sprawnego funkcjonowania w życiu (11 osób).

Wśród skutecznych sposobów rozwijania przedsiębiorczości badani wymienili te, które wiążą się z organizowaniem sytuacji służących: rozwiązywaniu problemów (27 osób), podejmowaniu decyzji i argumentowaniu (24 osoby), komunikowaniu się, negocjowaniu (23 osoby), pracy w zespole (18 osób), planowaniu działania (15 osób), rozpoznawaniu mocnych i słabych stron (13 osób), prezentacji pomysłów (19 osób). Pomocne w tym zakresie mogą być, zdaniem ankietowanych, m.in. metody i techniki aktywizujące, metody dramowe, prezentacja pomysłów i efektów pracy na forum klasy. Żaden z respondentów nie wskazał metody projektów ani strategii formułowania trafnych pytań jako istotnych w rozwijaniu przedsiębiorczości dzieci.

\section{Wnioski z badań własnych}

Na podstawie analizy uzyskanych wyników badań można zauważyć, że respondenci w rozwijaniu przedsiębiorczości uczniów deklarowali głównie stosowanie pytań z niższych poziomów organizacji myślenia, a więc tych, które wymagają mniej złożonych odpowiedzi i w niewielkim zakresie pobudzają uczniów do bardziej skomplikowanych operacji myślowych. Tymczasem dla rozwoju postaw przedsiębiorczych dzieci większe znaczenie mają pytania $\mathrm{z}$ wyższych form umiejętności myślenia, pytania wymagające refleksji, namysłu, ale jednocześnie pobudzające myślenie twórcze i krytyczne. Chociaż większość respondentów rozumie termin „przedsiębiorczość” i definiuje go szeroko, wykraczając poza ekonomiczne, wąskie ujęcie tego zagadnienia, oraz poprawnie zidentyfikowała cechy osoby przedsiębiorczej, to jednak wiedza badanych nauczycieli dotycząca strategii rozwijania przedsiębiorczości uczniów w młodszym wieku szkolnym była nieznaczna. Konieczne wydaje się zatem utrwalenie w świadomości już uczących, ale też studentów poczucia ważności i złożoności tej kompetencji. Wysoko rozbudzone poczucie własnej przedsiębiorczości pomaga docenić jej znaczenie w edukacji dzieci, jednak brak systematycznego przygotowania osłabia gotowość nauczycieli do podejmowania 
problematyki przedsiębiorczości w pracy z dziećmi albo wręcz utrudnia identyfikację tych sytuacji dydaktyczno-wychowawczych, w których rzeczywiście ono następuje. W poszukiwaniu modelu postępowania można odwołać się do kompetencji kreatywnych i twórczości. Waga tych ostatnich jako wskaźnika profesjonalizmu osoby wykonującej zawód nauczyciela jest dziś niepodważalna, czemu towarzyszy również rozumienie ich swoistości i potrzeba rozwijania (Adamek, Bałachowicz, 2013). Nadanie przedsiębiorczości podobnego statusu w hierarchii nauczycielskich kompetencji zdaje się konieczne. Do osiągnięcia tego celu prowadzić mogą dwie drogi. Pierwsza - to położenie nacisku na zwiększenie rangi edukacji przedsiębiorczej w programach uczelni pedagogicznych, jako że: „Kształcenie zawodowe nauczycieli musi uwzględniać związki edukacji z rynkiem pracy, ze sferą gospodarczą, z postępem technicznym" (Ir, 2016: 53). Druga to inicjowanie przez środowisko akademickie opracowania rzetelnych programów przedsiębiorczości dla najmłodszych oraz włączanie do tych działań nauczycieli praktyków. Dotychczasowe efekty podobnych poczynań są obiecujące, a sama edukacja przedsiębiorcza, do czego przekonują pogłębione studia nad tym zagadnieniem, wciąż ma nieodzowny, inspirujący potencjał.

\section{Zakończenie}

Kształtowanie postawy przedsiębiorczości powinno uwzględniać indywidualne zdolności, możliwości i osiągnięcia każdego ucznia, obejmować różne strategie myślenia twórczego i krytycznego oraz znaczącą rolę pytań wspierających ten proces. Pytania ukierunkowane na kształtowanie postawy przedsiębiorczej dzieci powinny rozwijać inicjatywę i poczucie sprawstwa, odwagę intelektualną i wytrwałość w dążeniu do celu, pobudzać dzieci do generowania pomysłów, wykorzystywania własnych zasobów, przewidywania konsekwencji działań, określenia własnych możliwości i szans, mocnych i słabych stron. Umożliwienie uczniom nabycia nawyku pytania samych siebie oraz kształtowanie umiejętności świadomego namysłu powinno stanowić główny cel działań nauczycielskich ukierunkowanych na kształtowanie kompetencji w zakresie przedsiębiorczości.

Literatura

References

Adamek, I., Bałachowicz J. (red.). (2011). Kompetencje kreatywne nauczyciela wczesnej edukacji dziecka. Kraków: Impuls.

Axelsson, K., Hägglund, S., Sandberg, A. (2015). Entrepreneurial Learning in Education. Preschool as a Take-Off for the Entrepreneurial Self. Journal of Education and Training, 2(2), 40-58.

Brzezińska, A., Schmidt, J. (2008). Przedsiębiorczość jako warunek udanego startu w dorosłość. W: A. Andrzejczak (red.), Przedsiębiorczość w edukacji. Poznań: Wydawnictwo Akademii Ekonomicznej, 21-23.

Fisher, R. (1999). Uczymy, jak myśleć. Warszawa: Wydawnictwa Szkolne i Pedagogiczne.

Ir, E. (2016). Nauczyciel w kontekście zmian społecznych. Pedagogika Przedszkolna $i$ Wczesnoszkolna, 1(7), 51-56.

Ir, E., Janiszewska, M. (2015). Hierarchia wartości nauczycieli przedszkoli miasta Krakowa. Pedagogika Przedszkolna i Wczesnoszkolna, 2(6), 73-80.

Klus-Stańska, D. (2000). Po co nam wiedza potoczna w szkole? W: K. Kruszewski (red.), Pedagogika w pokoju nauczycielskim. Warszawa: Wydawnictwa Szkolne i Pedagogiczne. 
Kłos, Z. (2012). Innowacyjność i przedsiębiorczość innowacyjna. Poznań: Wydawnictwo Politechniki Poznańskiej.

Kondracka-Szala, M., Malinowska, J. (2016). Studiowanie - czas na rozwijanie postawy przedsiębiorczej nauczycieli dziecka młodszego? Analiza porównawcza programów kształcenia w zakresie przedsiębiorczości na polskim i fińskim uniwersytecie. E-mentor, 3(65), 4-14.

Łobocki, M. (1984). Metody badań pedagogicznych. Warszawa: PWN.

Nęcka, E. (2001). Psychologia twórczości. Gdańsk: GWP.

Oelszlaeger-Kosturek, B. (2017). Przedsiębiorczość - istota i sposoby kształtowania w procesie edukacji wczesnoszkolnej. W: A. Murzyn, U. Szuścik (red.), Przedsiębiorczość jako wartość w edukacji. Katowice: Wydawnictwo Uniwersytetu Śląskiego, 154-166.

Paul, R., Binker, A.J.A., Charbonneau, M. (1996). Crictical Thinking. Handbook. Sonoma: State University.

Pilch, T. (1995). Zasady badań pedagogicznych. Warszawa: Wydawnictwo ŻAK.

Runco, M.A. (2003). Idea evaluatio, divergent thinking and creativity. W: M.A. Runco (red.), Critical creative processes. Creskill: Hampton Press, Inc.

Sternberg, R.J., Spear-Swerling, L. (2003). Jak nauczyć małe dzieci myślenia. Gdańsk: GWP.

Sufa, B., Grzywniak, C., Vaskevic-Buś, J. (2019). Kompetencje społeczne uczniów w młodszym wieku szkolnym. Prace Monograficzne - Uniwersytet Pedagogiczny im. Komisji Edukacji Narodowej, 924.

Sufa, B., Janas M. (2017). O rozwijaniu inicjatywności i przedsiębiorczości uczniów w młodszym wieku szkolnym. W: T. Łączek (red.), Wychowanie do sukcesu życiowego - wybór czy konieczność. Kielce: Wydawnictwo Uniwersytetu Jana Kochanowskiego.

Turska, D. (2006). Skuteczność ucznia. Lublin: Wydawnictwo UMCS.

Witkowski, L. (2007). Między pedagogika, filozofią i kulturą. Studia, eseje, szkice, t. 3. Warszawa: IBE.

Zoller E. (2009). A dlaczego? Jak odpowiadać na trudne pytania dzieci. Gdańsk: GWP.

Beata Sufa, dr nauk humanistycznych w zakresie pedagogiki, Uniwersytet Pedagogiczny im. Komisji Edukacji Narodowej w Krakowie. Obszar jej badań obejmuje: pedagogikę przedszkolną i wczesnoszkolną, psychopedagogikę twórczości, pedeutologię. Zainteresowania naukowe dotyczą: problematyki edukacji dzieci w wieku przedszkolnym i w młodszym wieku szkolnym, strategii rozwoju kreatywności i przedsiębiorczości dzieci w edukacji elementarnej, kompetencji nauczycieli przedszkola i edukacji wczesnoszkolnej.

Beata Sufa, PhD in Humanities in the field of pedagogy, Pedagogical University of Krakow. Her research area includes: pre-school and early school education, psycho-pedagogy of creativity, pedeutology. Academic interests relate to: education of preschool and younger schoolchildren, strategies for development of creativity and entrepreneurship of children in elementary education, competences of preschool and early school education teachers.

ORCID: https://orcid.org/0000-0001-9504-2374

\section{Adres/Address:}

Uniwersytet Pedagogiczny, im. Komisji Edukacji Narodowej w Krakowie

Instytut Pedagogiki Przedszkolnej i Szkolnej

ul. Ingardena 4

30-060 Kraków, Poland

e-mail: beata.sufa@up.krakow.pl 